\title{
Ozone production and loss rate measurements in the middle stratosphere
}

K. W. Jucks, D. G. Johnson, K. V. Chance, and W. A. Traub

Harvard-Smithsonian Center for Astrophysics, Cambridge, Massachusetts

R. J. Salawitch and R. A. Stachnik

Jet Propulsion Laboratory, Pasadena, California

\begin{abstract}
We present the first simultaneous measurements of $\mathrm{HO}_{x}, \mathrm{NO}_{x}$, and $\mathrm{Cl}_{x}$ radicals in the middle stratosphere obtained during a balloon flight at $34^{\circ} \mathrm{N}$ in September 1989, along with calculations from a photochemical model, to show that $\mathrm{NO}_{x}$ catalytic cycles dominate loss of ozone $\left(\mathrm{O}_{3}\right)$ for altitudes between 24 and $38 \mathrm{~km}$; the observed abundance of $\mathrm{ClO}$ is lower than that expected for altitudes above $30 \mathrm{~km}$ on the basis of models using recommended rates and cross sections, reducing the relative importance of the $\mathrm{Cl}_{x}$ catalytic cycles for loss of $\mathrm{O}_{3}$; and removal rates of $\mathrm{O}_{3}$ derived from observed concentrations of rate limiting $\mathrm{HO}_{x}, \mathrm{NO}_{x}$, and $\mathrm{Cl}_{x}$ radicals balance computed production rates for altitudes between 32 and $38 \mathrm{~km}$, a region where ozone is expected to be regulated primarily by photochemical processes.
\end{abstract}




\section{Introduction}

Understanding the rate of removal of stratospheric ozone through catalytic cycles involving $\mathrm{HO}_{x}\left(\mathrm{HO}_{2}\right.$ and $\mathrm{OH}), \mathrm{NO}_{x}\left(\mathrm{NO}_{2}\right.$ and $\left.\mathrm{NO}\right)$, and halogen $(\mathrm{ClO}$ and $\mathrm{BrO})$ radicals is essential for assessing the response of ozone to anthropogenic and natural perturbations such as industrial release of chlorofluorocarbons (CFCs) and halons, emission of nitrogen oxides from subsonic and supersonic aircraft, rising levels of $\mathrm{N}_{2} \mathrm{O}$ and $\mathrm{CH}_{4}$, and enhanced levels of sulfate aerosols following volcanic eruptions [World Meteorological Organization (WMO), 1991; Stolarski and Wesoky, 1993; Rodriguez et al., 1994].

Recent calculations from models of the midlatitude stratosphere give the following theoretical results: first, catalytic cycles involving $\mathrm{NO}_{x}$ radicals are expected to dominate ozone destruction from about 22 to $45 \mathrm{~km}$, while $\mathrm{HO}_{x}$ cycles dominate both above and below [McElroy et al.,1992; Rodriguez et al., 1994]; and second, modeled photochemical loss of ozone exceeds calculated production by $10 \%-50 \%$ in the upper stratosphere [Eluszkiewicz and Allen, 1993; Minschwaner et al., 1993; Crutzen et al., 1995; Siskind et al., 1995]. The latter result has been termed the "ozone deficit" problem, because at these altitudes, ozone is expected to be in photochemical equilibrium (production equaling loss), since the photochemical lifetime of ozone is much shorter than transport replacement times [Ko et al., 1989; Perliski et al., 1989].

The first theoretical result has recently been tested below $21 \mathrm{~km}$ by using in situ aircraft measurements of $\mathrm{HO}_{x}$, $\mathrm{NO}_{x}$, and $\mathrm{Cl}_{x}$ radicals [Wennberg et al., 1994]. These measurements, made under conditions of high aerosol loading as a result of the eruption of Mt. Pinatubo, are in good agreement with models that include the heterogeneous hydrolysis reaction of $\mathrm{N}_{2} \mathrm{O}_{5}$ on sulfate aerosols [Fahey et al., 1993; Salawitch et al., 1994].

The ozone deficit problem in the middle and upper stratosphere has been studied recently with the use of Atmospheric Trace Molecule Spectroscopy Experiment (ATMOS) measurements of $\mathrm{O}_{3}$, nitrogen oxides, and other trace gases [Minschwaner et al., 1993], HAlogen Occultation Experiment (HALOE) measurements of $\mathrm{O}_{3}, \mathrm{NO}_{2}$, and $\mathrm{HCl}$ [Crutzen et al., 1995], and a combination of Microwave Limb Sounder (MLS) measurements of $\mathrm{O}_{3}$ and $\mathrm{ClO}$ and Cryogenic Limb Atmospheric Limb Sounder (CLAES) measurements of $\mathrm{NO}_{2}$ [Dessler et al., 1996]. Minschwaner et al. [1993] concluded that production and loss of $\mathrm{O}_{3}$ are in balance near $40 \mathrm{~km}$ altitude, provided models allow for production of $\mathrm{HCl}$ from a branch of the reaction of $\mathrm{ClO}+\mathrm{OH}$, as suggested by theoretical studies constrained by ATMOS measurements of $\mathrm{HCl}$ and
$\mathrm{ClONO}_{2}[$ McElroy and Salawitch, 1989] and submillimeter heterodyne measurements of $\mathrm{ClO}$ and $\mathrm{HCl}$ [Stachnik et al., 1992]. Crutzen et al. [1995] concluded production and loss of $\mathrm{O}_{3}$ were in closer balance than was suggested by other analyses of satellite data [Eluszkiewicz and Allen, 1993; Siskind et al., 1995], but their conclusions are affected by the use of $\mathrm{O}_{3}$ from HALOE, which is systematically lower than $\mathrm{O}_{3}$ measured by MLS. Dessler et al. [1996] concluded ozone production and loss rates constrained by measured $\mathrm{ClO}, \mathrm{NO}_{2}$, and $\mathrm{O}_{3}$ from MLS are nearly in balance at $40 \mathrm{~km}$. All previous studies lack direct, simultaneous measurements of $\mathrm{HO}_{x}, \mathrm{Cl}_{x}$, and $\mathrm{NO}_{x}$ radicals.

In this paper we use the the first simultaneous measurement of concentrations of $\mathrm{HO}_{x}, \mathrm{NO}_{x}, \mathrm{Cl}_{x}$, and radical precursors throughout the middle stratosphere [Chance et al., 1996] to calculate the photochemical removal rate of ozone between 20 and $38 \mathrm{~km}$. Our analysis uses simultaneous measurements of a complete set of radicals to determine experimentally the ordering of the loss cycles of ozone in the middle stratosphere and to study the ozone deficit problem.

Diurnally averaged photochemical removal rates of $\mathrm{O}_{3}$ by each family of radicals are determined in two ways: from direct measurements of radical concentrations (radical method) and from radical concentrations calculated by a photochemical model constrained by measurements of radical precursors (precursor method). The radical method is used to derive empirical measures of the total loss rate of ozone as well as the relative removal rate by each family of radicals that regulate the abundance of ozone in the middle stratosphere. The precursor method provides a basis for comparing the empirical loss rates to theoretical rates constrained by appropriate environmental conditions, represented by the observed concentrations of longlived radical precursors. Empirical loss rates found by using the radical method demonstrate that catalytic cycles involving $\mathrm{NO}_{x}$ radicals dominate photochemical removal of $\mathrm{O}_{3}$ in the middle stratosphere, consistent with theoretical predictions using the precursor method. Our measurements demonstrate that production and loss rates of ozone (found by using both methods) balance to within the uncertainty of measurement (10\%) for altitudes between 31 and $38 \mathrm{~km}$. This finding, which reconciles a long-standing discrepancy in stratospheric chemistry, is due primarily to our observation of a lower abundance of $\mathrm{ClO}$ than that calculated by models that allow for production of $\mathrm{HCl}$ only from reaction of $\mathrm{Cl}$ and hydrocarbons and $\mathrm{HO}_{2}$ [Chance et al., 1996]. 


\section{Measurements and Model}

Descriptions of the measurement technique and analysis methods [Traub et al., 1991; Johnson et al., 1995; Waters et al., 1984] have been published previously; thus only a brief summary is given here. Data were acquired on a balloon flight launched from Ft. Sumner, New Mexico $\left(34^{\circ} \mathrm{N}, 104^{\circ} \mathrm{W}\right)$, from $1714 \mathrm{UT}$ on September 26, 1989, until 1832 UT on September 27, 1989, with the exception of a 4-hour telemetry gap prior to sunrise on September 27. Concentrations of $\mathrm{ClO}$ were measured at midday between altitudes of 20 and $40 \mathrm{~km}$ with the Jet Propulsion Laboratory (JPL) Balloon Microwave Limb Sounder (BMLS), which senses microwave emission from the limb. Concentration profiles of $\mathrm{OH}, \mathrm{HO}_{2}, \mathrm{H}_{2} \mathrm{O}_{2}, \mathrm{HOCl}, \mathrm{HCl}$, $\mathrm{NO}_{2}, \mathrm{HNO}_{3}, \mathrm{~N}_{2} \mathrm{O}, \mathrm{H}_{2} \mathrm{O}, \mathrm{O}_{3}$, and temperature were measured throughout a diurnal cycle with the Smithsonian Astrophysical Observatory (SAO) far-infrared Fourier transform spectrometer (FIRS 2), which detects atmospheric thermal emission in a limb-viewing geometry.

The constrained photochemical model used in our analysis balances, over a 24-hour period, the production and loss of 35 reactive gases for the temperature, pressure, and latitude at which the observations were obtained [Salawitch et al., 1994]. Standard reaction rates and absorption cross sections were used [DeMore et al., 1994], except that photolysis cross sections for $\mathrm{H}_{2} \mathrm{O}_{2}$ and $\mathrm{HNO}_{4}$ were extrapolated to longer wavelengths to accurately represent photolysis of these molecules at large solar zenith angles. A reaction probability of 0.1 was used for the heterogeneous hydrolysis of $\mathrm{N}_{2} \mathrm{O}_{5}$ [DeMore et al., 1994]. The altitude profile for the surface area density of sulfate aerosols was adopted from Stratospheric Aerosol and Gas Experiment (SAGE) II extinction measurements for this time period [WMO, 1991]. The heterogeneous hydrolysis of $\mathrm{ClNO}_{3}$ and $\mathrm{BrNO}_{3}$ was included [Hanson and Ravishankara, 1994, 1995; Hanson and Lovejoy, 1995] but have a negligible effect on model results for the temperatures and aerosol loading of these observations. Other inputs to the constrained photochemical model include profiles of temperature, $\mathrm{O}_{3}$, and $\mathrm{H}_{2} \mathrm{O}$ measured by FIRS 2 . Profiles of $\mathrm{CH}_{4}$, odd nitrogen $\left(\mathrm{NO}_{y}=\mathrm{NO}+\mathrm{NO}_{2}+\mathrm{NO}_{3}+\right.$ $\left.2 \times \mathrm{N}_{2} \mathrm{O}_{5}+\mathrm{HNO}_{2}+\mathrm{HNO}_{3}+\mathrm{HNO}_{4}+\mathrm{ClNO}_{3}+\mathrm{BrNO}_{3}\right)$, inorganic chlorine $\left(\mathrm{Cl}_{y}=\mathrm{HCl}+\mathrm{ClNO}_{3}+\mathrm{ClO}+\mathrm{HOCl}+\right.$ $\left.\mathrm{Cl}+\mathrm{OClO}+2 \mathrm{xCl}_{2} \mathrm{O}_{2}+\mathrm{ClOO}\right)$, and inorganic bromine $\left(\mathrm{Br}_{y}=\mathrm{HBr}+\mathrm{BrONO}_{2}+\mathrm{BrO}+\mathrm{HOBr}+\mathrm{BrCl}\right)$ have been inferred from the FIRS 2 measurement of $\mathrm{N}_{2} \mathrm{O}$ by using relations derived from previous satellite [Gunson et al., 1990] and in situ observations [Fahey et al., 1990; Woodbridge et al., 1995; Schauffler et al., 1993]. The maximum $\mathrm{Br}_{y}$ at high altitude is assumed to be $21 \mathrm{pptv}$.

\section{Comparison of Measurements and Model}

Chance et al. [1996] have presented a detailed discussion of model uncertainties, as well as a comparison between measurements of $\mathrm{HO}_{x}, \mathrm{NO}_{x}$, and $\mathrm{Cl}_{x}$ radicals and profiles calculated by using the model presented here. We summarize below the main conclusions of Chance et al. [1996] as they apply to the analysis to follow.

Calculated concentrations of $\mathrm{OH}$ and $\mathrm{HO}_{2}$ are in satisfactory agreement with observations throughout the observed altitude range, 20 to $38 \mathrm{~km}$, with the exception that the observed abundances of $\mathrm{OH}$ exceed calculations by more than $20 \%$, the $2 \sigma$ measurement uncertainty, at 38 $\mathrm{km}$. The $\mathrm{NO}_{2}$ and $\mathrm{HNO}_{3}$ measurements are also in good agreement with theoretical profiles except at $24 \mathrm{~km}$ (near the peak mixing ratio of $\mathrm{HNO}_{3}$ ), where measured concentrations of $\mathrm{HNO}_{3}$ exceed calculated values by about $15 \%$, larger than the 1-sigma uncertainty of the measurement. Above $30 \mathrm{~km}$ the measurements of $\mathrm{Cl}_{y}$ species $(\mathrm{ClO}, \mathrm{HCl}$, and $\mathrm{HOCl}$ ) are not in agreement with the values calculated assuming a conventional set of reactions, which assumes the only sources of $\mathrm{HCl}$ are the reactions of $\mathrm{Cl}$ with hydrocarbons and $\mathrm{HO}_{2}$ (a typical assumption of current multidimensional models of atmospheric photochemistry and transport [Prather and Remsberg, 1993]). The conventional model tends to overpredict the reactive chlorine $(\mathrm{ClO}$ and $\mathrm{HOCl})$ while it underpredicts $\mathrm{HCl}$. The measured concentrations of $\mathrm{Cl}_{y}$ species are in good agreement with a second model that includes the additional production of $\mathrm{HCl}$ by the reaction of $\mathrm{ClO}$ with $\mathrm{OH}$ with a $10 \%$ branching ratio. DeMore et al. [1994] suggest a lower limit of $0 \%$, and an upper limit of $14 \%$, for production of $\mathrm{HCl}$ from the $\mathrm{ClO}+\mathrm{OH}$ reaction. Laboratory measurements of the production of $\mathrm{HCl}$ from this reaction, which would involve breaking and reforming multiple chemical bonds, give ambiguous results. While this reaction is not the only pathway for additional production of $\mathrm{HCl}$ that might be consistent with the simultaneous measurement of $\mathrm{ClO}, \mathrm{HOCl}$, and $\mathrm{HCl}$, it is the only pathway within the recommended uncertainties of current kinetic measurements [DeMore et al., 1994].

There are large uncertainties in many important reaction rates used by the photochemical model, which when considered collectively may account for the differences between the measured and modeled $\mathrm{Cl}_{y}$ partitioning. However, because the model shows reasonable agreement with the measured $\mathrm{HO}_{x}$ and $\mathrm{NO}_{y}$ species, only the uncertainties in rates for reactions that directly involve $\mathrm{Cl}_{y}$ partitioning need to be considered in discussing the overprediction of $\mathrm{ClO}$ by the conventional model. Specifically, the rates of the reactions in which $\mathrm{HCl}$ is created $(\mathrm{Cl}+$ 
$\left.\mathrm{CH}_{4} \rightarrow \mathrm{HCl}+\mathrm{CH}_{3}\right)$ or destroyed $\left(\mathrm{HCl}+\mathrm{OH} \rightarrow \mathrm{H}_{2} \mathrm{O}+\right.$ $\mathrm{Cl})$ will have the most direct impact on the partitioning of $\mathrm{Cl}_{y}$ species. DeMore et al. [1994] list uncertainties for these reactions at $250 \mathrm{~K}$ of about $21 \%$ and $28 \%$, respectively. The extreme value for the rate of both reactions is required to account for the differences between the measurements and the conventional reaction set. Michelsen et al. [1996] present a thorough investigation of the kinetics of these reactions and conclude that the partitioning of $\mathrm{Cl}_{y}$ measured by the ATMOS and Millimeter-wave Atmospheric Sounder (MAS) instruments during the ATLAS 2 and ATLAS 3 space shuttle missions cannot be explained unless an additional source of $\mathrm{HCl}$, not present in the conventional reaction set, is allowed.

A further source of uncertainty in the model is the estimation of $\mathrm{Cl}_{y}, \mathrm{NO}_{y}$, and $\mathrm{CH}_{4}$ from relationships with $\mathrm{N}_{2}$ O. These relationships have been well established throughout the altitude range of these measurements by using observations from ATMOS at midlatitudes [Gunson et al., 1990]. The uncertainties in those quantities are proportional to the measurements of $\mathrm{N}_{2} \mathrm{O}$, about $10 \%$, and are affected by the amount that the air being measured deviates from midlatitude conditions. Chance et al. [1996] eliminated the effect of uncertainties in $\mathrm{Cl}_{y}$ by examining comparisons between theory and observations for the ratios $[\mathrm{ClO}] /[\mathrm{HCl}]$ and $[\mathrm{HOCl}] /[\mathrm{HCl}]$. Uncertainties in $\mathrm{CH}_{4}$, whose oxidation provides a minor source of $\mathrm{HO}_{x}$ radicals, have only a minor impact on our photochemical simulations. Corroborating evidence for the existence of such an additional pathway for production of $\mathrm{HCl}$ is provided by Upper Atmosphere Research Satellite (UARS) measurements of $\mathrm{O}_{3}, \mathrm{H}_{2} \mathrm{O}, \mathrm{HCl}, \mathrm{ClO}$, and $\mathrm{ClNO}_{3}$ [Eckman et al., 1995; Dessler et al., 1996].

\section{4. $\mathrm{O}_{3}$ Photochemical Loss and Production Rates}

Ozone and atomic oxygen $(\mathrm{O})$, together defined as odd oxygen $\left(\mathrm{O}_{x}\right)$, are in rapid photochemical steady state via the reactions $\mathrm{O}_{3}+h \mathrm{v} \rightarrow \mathrm{O}+\mathrm{O}_{2}$ and $\mathrm{O}+\mathrm{O}_{2}+\mathrm{M} \rightarrow$ $\mathrm{O}_{3}+\mathrm{M}$. Throughout the stratospheric altitude range discussed in this paper, $\mathrm{O}_{3}$ represents more than $99 \%$ of total odd oxygen, and thus a change in the abundance of odd oxygen is considered as equivalent to a change in the abundance of $\mathrm{O}_{3}$. Oxides of hydrogen, nitrogen, chlorine, and bromine regulate the abundance of $\mathrm{O}_{x}$ in the middle stratosphere through a variety of reactions that catalyze the self-reaction of $\mathrm{O}_{3}$ or the reaction of $\mathrm{O}_{3}$ and O. Since each reaction sequence listed below accounts for the loss of two molecules of $\mathrm{O}_{x}$, the net loss rates are determined by doubling the diurnally averaged rate of the limiting step of each cycle. The rate-limiting steps for each cycle are indicated by the number label.

The role of $\mathrm{HO}_{x}$ radicals in regulating the abundance of odd oxygen was first noted by Bates and Nicolet [1950]. The important cycles are

$$
\begin{aligned}
\mathrm{OH}+\mathrm{O}_{3} & \rightarrow \mathrm{HO}_{2}+\mathrm{O}_{2}, \\
\mathrm{HO}_{2}+\mathrm{O}_{3} & \rightarrow \mathrm{OH}+\mathrm{O}_{2}+\mathrm{O}_{2}, \\
\text { Net }: 2 \mathrm{O}_{3} & \rightarrow 3 \mathrm{O}_{2}
\end{aligned}
$$

which is significant in the lower stratosphere and

$$
\begin{aligned}
\mathrm{OH}+\mathrm{O}_{3} & \rightarrow \mathrm{HO}_{2}+\mathrm{O}_{2}, \\
\mathrm{HO}_{2}+\mathrm{O} & \rightarrow \mathrm{OH}+\mathrm{O}_{2}, \\
\text { Net: } \mathrm{O}_{3}+\mathrm{O} & \rightarrow 2 \mathrm{O}_{2} ;
\end{aligned}
$$

with other cycles accounting for less than $5 \%$ of ozone loss by $\mathrm{HO}_{x}$ species between 35 and $40 \mathrm{~km}$ and less than $1 \%$ below $35 \mathrm{~km}$.

Crutzen [1970] and Johnston [1971] established the importance of removal of odd oxygen by cycles involving $\mathrm{NO}_{x}$ :

$$
\begin{aligned}
\mathrm{NO}+\mathrm{O}_{3} & \rightarrow \mathrm{NO}_{2}+\mathrm{O}_{2}, \\
\mathrm{NO}_{2}+\mathrm{O} & \rightarrow \mathrm{NO}+\mathrm{O}_{2}, \\
\mathrm{Net}: \mathrm{O}_{3}+\mathrm{O} & \rightarrow 2 \mathrm{O}_{2} ; \\
\mathrm{NO}+\mathrm{O}_{3} & \rightarrow \mathrm{NO}_{2}+\mathrm{O}_{2}, \\
\mathrm{NO}_{2}+\mathrm{O}_{3} & \rightarrow \mathrm{NO}_{3}+\mathrm{O}_{2}, \\
\mathrm{NO}_{3}+h v & \rightarrow \mathrm{NO}+\mathrm{O}_{2}, \\
\mathrm{Net}: 2 \mathrm{O}_{3} & \rightarrow 3 \mathrm{O}_{2} ;
\end{aligned}
$$

where only $10 \%$ of $\mathrm{NO}_{3}$ photolysis produces $\mathrm{NO}$ to complete this cycle.

Molina and Rowland [1974] and Stolarski and Cicerone [1974], and Wofsy et al. [1975] drew attention to removal of odd oxygen by chlorine and bromine radicals, respectively. Loss occurs primarily through the cycles

$$
\begin{aligned}
Z \mathrm{O}+\mathrm{O} & \rightarrow Z+\mathrm{O}_{2} \\
Z+\mathrm{O}_{3} & \rightarrow \mathrm{ZO}+\mathrm{O}_{2}, \\
\mathrm{Net}: \mathrm{O}_{3}+\mathrm{O} & \rightarrow 2 \mathrm{O}_{2} \\
\mathrm{HO}_{2}+\mathrm{ZO} & \rightarrow \mathrm{HOZ}+\mathrm{O}_{2}, \\
\mathrm{HOZ}+h v & \rightarrow \mathrm{OH}+Z \\
Z+\mathrm{O}_{3} & \rightarrow \mathrm{ZO}+\mathrm{O}_{2} \\
\mathrm{OH}+\mathrm{O}_{3} & \rightarrow \mathrm{HO}_{2}+\mathrm{O}_{2}, \\
\mathrm{Net}: 2 \mathrm{O}_{3} & \rightarrow 3 \mathrm{O}_{2} ;
\end{aligned}
$$


where $Z=\mathrm{Cl}$ or $\mathrm{Br}$, as well as through the cycle

$$
\begin{aligned}
\mathrm{BrO}+\mathrm{ClO} & \rightarrow \mathrm{Br}+\mathrm{Cl}+\mathrm{O}_{2}, \\
\mathrm{Br}+\mathrm{O}_{3} & \rightarrow \mathrm{BrO}+\mathrm{O}_{2}, \\
\mathrm{Cl}+\mathrm{O}_{3} & \rightarrow \mathrm{ClO}+\mathrm{O}_{2}, \\
\mathrm{Net}: 2 \mathrm{O}_{3} & \rightarrow 3 \mathrm{O}_{2}
\end{aligned}
$$

which is a major loss cycle for $\mathrm{O}_{3}$ in the Antarctic spring [McElroy et al., 1986].

Loss of odd oxygen proceeds also by the reaction [Chapman, 1930]

$$
\mathrm{O}+\mathrm{O}_{3} \rightarrow 2 \mathrm{O}_{2},
$$

which is a minor sink in the middle stratosphere. Odd oxygen is produced by photolysis of $\mathrm{O}_{2}$ at wavelengths shorter than $242 \mathrm{~nm}$, with a small contribution from the reaction of $\mathrm{CH}_{3} \mathrm{O}_{2}$ and $\mathrm{NO}$ [Wennberg et al., 1994].

The precursor method uses a photochemical model, constrained by our measurements of $\mathrm{O}_{3}, \mathrm{H}_{2} \mathrm{O}, \mathrm{N}_{2} \mathrm{O}$, and temperature, to predict the abundances of $\mathrm{O}, \mathrm{HO}_{2}, \mathrm{OH}$, $\mathrm{NO}_{2}, \mathrm{ClO}$, and $\mathrm{BrO}$ over a 24 -hour period. These abundances are used to calculate the rates of reactions (1)-(8). The loss rates of $\mathrm{O}_{3}$ are integrated over 24 hours, by using reaction rate constants from DeMore et al. [1994], and summed to evaluate the the rates of the $\mathrm{HO}_{x}$ (rate-limiting reactions (1) and (2)), $\mathrm{NO}_{x}$ (reactions (3) and (4)), halogen (reactions (5), (6), and (7)), and $\mathrm{O}+\mathrm{O}_{3}$ (reaction (8)) loss cycles.

The radical method uses direct measurements of $\mathrm{HO}_{2}$, $\mathrm{OH}, \mathrm{NO}_{2}$, and $\mathrm{ClO}$ to calculate the rates of reactions (1)(8). The measurements are interpolated onto a finer time grid by normalizing the abundances calculated by the constrained photochemical model for each of these molecules to best fit the data throughout the 24-hour cycle. This process is shown in Figure 1 for a representative altitude of $32 \mathrm{~km}$ with concentrations that have been adapted from the model and measurement results presented by Chance et al. [1996]. We show the $1 \sigma$ uncertainties in the observations which include systematic uncertainties. We note that the model is in excellent agreement with the data even before scaling for $\mathrm{HO}_{2}$ and $\mathrm{NO}_{2}$, while the $\mathrm{ClO}$ measurement is significantly lower than the results from the conventional photochemical model.

Figure 2 compares the removal rate of odd oxygen from the radical and precursor methods, partitioned into each radical family as described in the cycles listed above. The uncertainties listed here include the $1 \sigma$ uncertainties from the measurements plus any residuals between the observed and normalized concentrations. The precursor method calculations are based on the results from the constrained
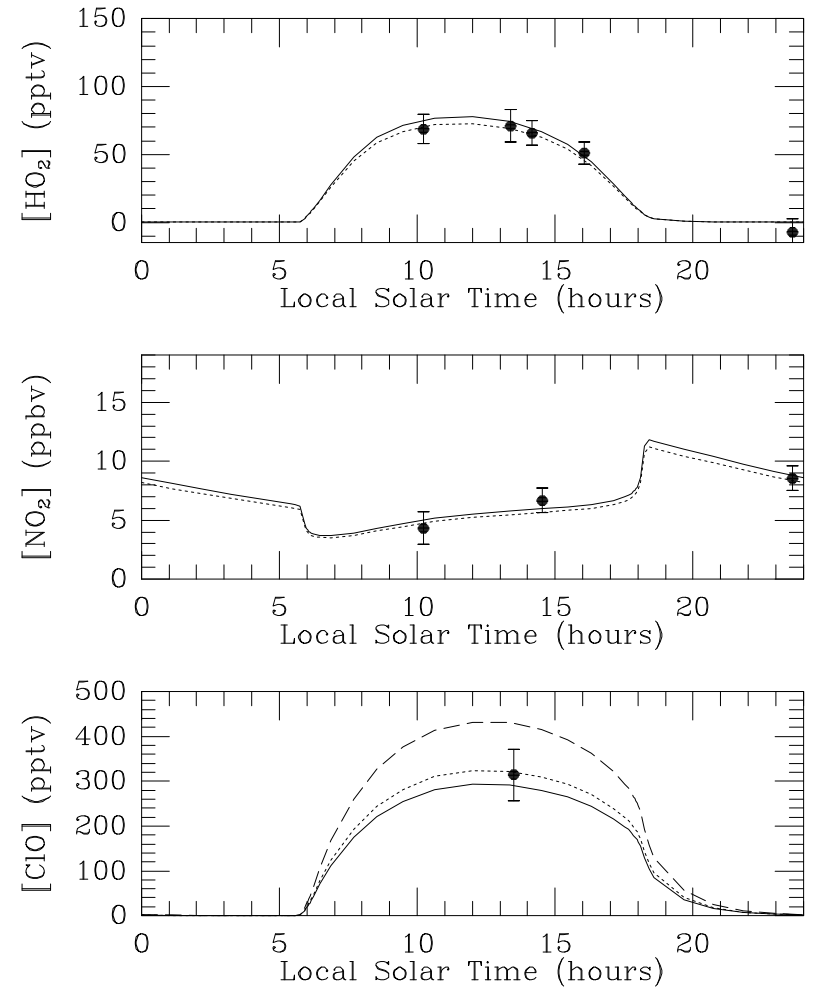

Figure 1. Individual concentration measurements (solid circles) along with the modeled diurnal concentrations (solid curves) and the corresponding scaled concentrations (dotted curves) for $\mathrm{HO}_{2}, \mathrm{NO}_{2}$, and $\mathrm{ClO}$ at $32 \mathrm{~km}$. The $1 \sigma$ uncertainties are dominated by random measurement errors but include estimated systematic errors. The modeled $\mathrm{ClO}$ has two curves, one including (solid curve) and one not including (dashed curve) production of $\mathrm{HCl}$ from the $\mathrm{ClO}+\mathrm{OH}$ reaction. For this altitude the average integration time for each measurement is 22,42 , and 50 min for $\mathrm{HO}_{2}, \mathrm{NO}_{2}$, and $\mathrm{ClO}$, respectively; each integration comprises several shorter observations spread over average corresponding intervals of 2, 5.5, and 6 hours, respectively (see Chance et al. [1996] for details).

photochemical model, whose uncertainties were discussed in some detail earlier and by Chance et al. [1996]. The loss rate uncertainties from the radical method depend also on the uncertainty of the rate of the limiting steps. At the lower altitudes of this study the measurement uncertainties dominate the overall uncertainty. At the higher altitudes, where the measurement uncertainties are smaller, the dominant odd oxygen loss cycles involve reactions (2), (3), (5) and (8). Reaction (5) is dominated by the ClO cycle, which is more than 2 orders of magnitude more effec- 


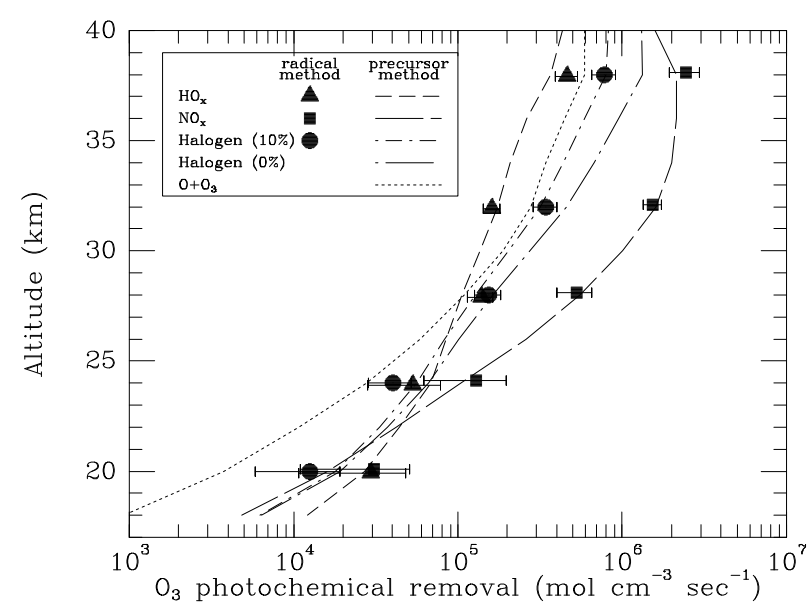

Figure 2. $\mathrm{HO}_{x}$ (solid triangles), $\mathrm{NO}_{x}$ (solid squares), and halogen (solid circles) catalyzed loss rates of $\mathrm{O}_{3}$ inferred from radical method and calculated by using the precursor method (curves). Two halogen catalyzed precursor method loss calculations are illustrated: one assuming $\mathrm{HCl}$ production only from $\mathrm{Cl}$ reacting with hydrocarbons and one with additional production of $\mathrm{HCl}$ from a $10 \%$ branch of the $\mathrm{OH}+\mathrm{ClO}$ reaction (see text). The $\mathrm{O}+\mathrm{O}_{3}$ reaction curve can be considered to represent both the radical and precursor methods since $\mathrm{O}$ is inferred directly from measurements of $\mathrm{O}_{3}$, which is the precursor for $\mathrm{O}$. The symbols are offset in altitude for clarity.

tive than the $\mathrm{BrO}$ reaction at destroying odd oxygen above $30 \mathrm{~km}$. As a result, uncertainties in the loss rate of $\mathrm{O}_{3}$ at these altitudes due to the use of calculated profiles for $\mathrm{BrO}$ are small compared to other sources of error. Using the average measured temperature of $240 \mathrm{~K}$ for these altitudes, the uncertainties in the rate constants for reactions (2), (3), (5), and (8) are $30 \%, 21 \%, 27 \%$, and $40 \%$, respectively [DeMore et al., 1994]. Because these uncertainties will systematically affect the rates from both the radical and precursor methods and will not affect the comparisons of the two quantities, they are not included in Figure 2. This figure illustrates that the general behavior of the removal rates of odd oxygen inferred from the observed concentration of radicals is in agreement with theory for the $\mathrm{HO}_{x}$ and $\mathrm{NO}_{x}$ families of radicals. Above $32 \mathrm{~km}$ the lower abundance of $\mathrm{ClO}$ calculated by the second model gives removal rates of ozone by halogens that are reduced by as much as $40 \%$ compared to the values calculated by using the conventional set of reactions. This difference is larger than the uncertainty in the rate constant for reaction (5).

The fractional contribution of each radical family to loss of odd oxygen is shown in Figure 3. Cycles involv-

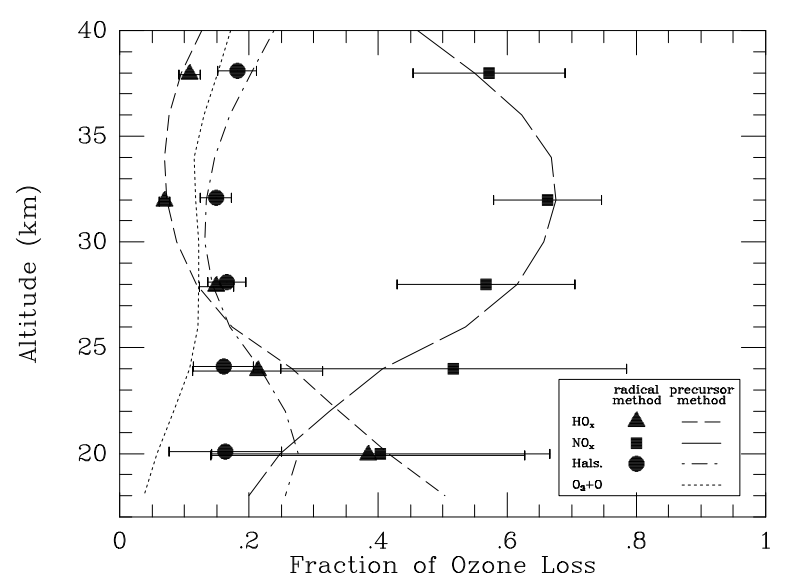

Figure 3. Fractional total loss of odd oxygen from the $\mathrm{HO}_{x}, \mathrm{NO}_{x}$, and halogen catalytic cycles shown as a function of altitude, as inferred from the radical method, using measurements of $\mathrm{HO}_{2}, \mathrm{NO}_{2}, \mathrm{ClO}$, and $\mathrm{O}_{3}$ (symbols) and from the precursor method (curves). The curves for the precursor method use the model that assumes additional $\mathrm{HCl}$ production from a $10 \%$ branch of the $\mathrm{OH}+\mathrm{ClO}$ reaction.

ing $\mathrm{NO}_{x}$ radicals dominate the loss of ozone between altitudes of 24 and $38 \mathrm{~km}$, contributing a maximum of $66 \%$ to the total loss rate at $32 \mathrm{~km}$. In contrast to observations obtained during the Stratospheric Photochemistry, Aerosols, and Dynamics Expedition (SPADE) [Wennberg et al., 1994], our measurements also suggest that loss of odd oxygen due to $\mathrm{NO}_{x}$ cycles is comparable to loss due to halogen cycles near $20 \mathrm{~km}$. The SPADE measurements showed loss of odd oxygen due to $\mathrm{NO}_{x}$ cycles to be a factor of 2-4 slower than loss due to halogen and $\mathrm{HO}_{x}$ cycles. However, the large uncertainties of our measurements at these altitudes make it difficult to determine precisely the ordering of the loss cycles. The balloon-borne observations were obtained in 1989 , when concentrations of $\mathrm{Cl}_{y}$ were approximately $14 \%$ lower than contemporary levels [Elkins et al., 1993] and sulfate aerosol loading was about a factor of 5 less than values encountered during SPADE, which were elevated due to the eruption of Mt. Pinatubo in the summer of 1991. Both factors contribute to a larger relative contribution by $\mathrm{NO}_{x}$ cycles to odd oxygen removal in the lower stratosphere during 1989.

Figure 4 illustrates diurnally averaged total loss rates for odd oxygen inferred from both the radical and precursor methods, as well as production rates from photolysis of $\mathrm{O}_{2}$ calculated by using a radiative transfer model that includes Rayleigh and aerosol scattering [Prather, 1981; 


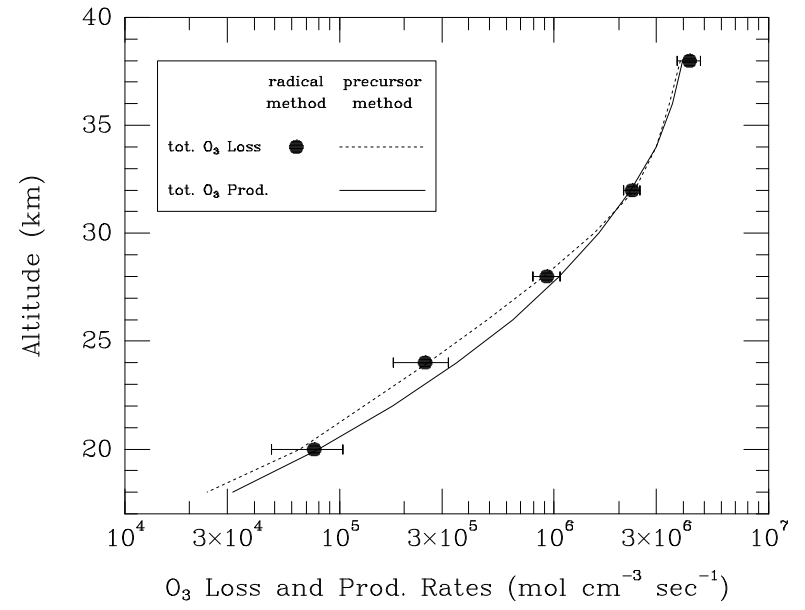

Figure 4. Loss rates of ozone calculated with the radical method (see text) from direct measurements of $\mathrm{HO}_{2}$, $\mathrm{NO}_{2}, \mathrm{ClO}$, and $\mathrm{O}_{3}$ (solid circles), loss rates calculated by using the precursor method using a model that assumes $\mathrm{HCl}$ production from a $10 \%$ branch of the $\mathrm{ClO}+\mathrm{OH}$ reaction (dotted curve), and production rates of $\mathrm{O}_{3}$ (solid curve) calculated primarily from photodissociation of $\mathrm{O}_{2}$ (see text) and constrained by measurements of $\mathrm{O}_{3}$ and temperature.

Minschwaner et al., 1993]. The error bars are derived from the uncertainties presented in Figure 2 for each of the radical families added in quadrature. Three conclusions can be drawn from this figure. First, total odd oxygen loss rates inferred from the observed concentrations of radicals (radical method) agree with theoretical loss rates (precursor method) to within the measurement uncertainty at all altitudes. Second, between 31 and $38 \mathrm{~km}$, where the photochemical lifetime of ozone is short compared to transport timescales, we find that production and loss rates of odd oxygen calculated by using both methods balance to within the uncertainty of the measurements of the radicals (approximately 10\%), in contrast to previous studies (which lacked simultaneous measurements of $\mathrm{HO}_{2}, \mathrm{NO}_{2}$, and $\mathrm{ClO}$ ) that reported loss rates up to $50 \%$ greater than production rates [Crutzen and Schmailzl, 1983; Froidevaux et al., 1985; Jackman et al., 1986; McElroy and Salawitch, 1989; Eluszkiewicz and Allen, 1993]. Third, rates of production below $31 \mathrm{~km}$ exceed by $30 \%$ to $40 \%$ the loss rates calculated by using both methods, indicating that this region is a net photochemical source region for $\mathrm{O}_{3}$. This imbalance is consistent with results of two-dimensional photochemical transport models that show net ozone production from this region [Jackman et al., 1986; Perliski et al., 1989].
At the altitudes at which we measure a balance between production and loss of odd oxygen, 32 and $38 \mathrm{~km}$, the dominant odd oxygen loss cycles are the same as those discussed for Figure 2, with reaction (3) contributing more than $60 \%$ to the total odd oxygen loss. By weighting the uncertainties of these reaction rates by the relative contributions from each of these cycles we calculate a net reaction rate uncertainty of $23 \%$ in the calculated total loss rate for the radical method. This value is of the order of the estimated uncertainty (20\%) in the production of $\mathrm{O}_{3}$ [Minschwaner et al., 1993] and is larger than the uncertainties $(10 \%)$ in the loss rates due to the uncertainty of the measurements of the radicals at these altitudes.

\section{Discussion}

Our finding that production and measured loss of of odd oxygen balance for altitudes between 31 and $38 \mathrm{~km}$ differs from the results of previous studies for two reasons: (1) we observe lower concentrations of $\mathrm{ClO}$ at these altitudes than are predicted by those models which assume that production of $\mathrm{HCl}$ occurs only by reaction of $\mathrm{Cl}$ with hydrocarbons and $\mathrm{HO}_{2}$ [Chance et al., 1996], as illustrated in Figure 1, and (2) we use a formulation for photolysis of $\mathrm{O}_{2}$ that results in deeper penetration of ultraviolet radiation [Minschwaner et al., 1993], and better agreement with measured transmittances, than is found by using the formulation recommended by $W M O$ [1986]. Including the additional source of $\mathrm{HCl}$ lowers the total modeled loss rate of odd oxygen by about $17 \%$ near $38 \mathrm{~km}$ (see Figures 2 and 4), resulting in close agreement between production and loss of ozone found by using the precursor method. Although this difference is less than the combined uncertainties in the production and loss rates stated above, the comparisons between the measured radicals involved in the rate limiting steps for the ozone loss cycles and the photochemical model presented here and by Chance et al. [1996] show that observed concentrations of $\mathrm{HO}_{2}$ and $\mathrm{NO}_{2}$ are well simulated, while $\mathrm{ClO}$ (and hence its contribution to loss of $\mathrm{O}_{3}$ ) is overestimated by the conventional model.

Most current models used to assess the impact of anthropogenic emission of halogens on ozone overestimate the abundance of $\mathrm{ClO}$ in the upper stratosphere by neglecting the possibility of an additional pathway for production of HCl [Prather and Remsberg, 1993]. Our observations demonstrate that these models overestimate the relative contribution of halogen cycles to the removal rate of odd oxygen at altitudes near $40 \mathrm{~km}$. The predicted decrease in ozone near $40 \mathrm{~km}$ resulting from the buildup of halogens during the past several decades is mitigated by $50 \%$, if an 
additional pathway for production of $\mathrm{HCl}$ is included in models, resulting in closer agreement between observed and predicted trends in $\mathrm{O}_{3}$ at these altitudes [Chandra et al., 1993]. Above $45 \mathrm{~km}, \mathrm{HO}_{x}$ catalyzed cycles dominate ozone loss, with the importance of halogen cycles decreasing with increasing altitude into the mesosphere. Inclusion of an additional source of $\mathrm{HCl}$ may not be sufficient to solve the imbalance between modeled production and loss at altitudes at which reaction (2) dominates loss of odd oxygen [Crutzen and Schmailzl, 1983; Froidevaux et al., 1985; Eluszkiewicz and Allen, 1993]. New observations of $\mathrm{HO}_{x}$ radicals, measured simultaneously with $\mathrm{O}_{3}, \mathrm{NO}_{2}$, and $\mathrm{ClO}$, will be necessary to advance our understanding of the budget of $\mathrm{O}_{3}$ at altitudes higher than $38 \mathrm{~km}$.

Numerous recent atmospheric observations are consistent with our findings that $\mathrm{ClO}$ is overpredicted by models. The study of Minschwaner et al. [1993] concludes, on the basis of constraints imposed by ATMOS measurements of $\mathrm{O}_{3}, \mathrm{NO}, \mathrm{NO}_{2}, \mathrm{~N}_{2} \mathrm{O}_{5}, \mathrm{HNO}_{3}, \mathrm{ClNO}_{3}, \mathrm{HCl}, \mathrm{H}_{2} \mathrm{O}$, and $\mathrm{CH}_{4}$, that production and loss of odd oxygen will balance near $40 \mathrm{~km}$ if a minor branch of the reaction of $\mathrm{ClO}$ with $\mathrm{OH}$ results in production of $\mathrm{HCl}$. The more recent study of ATMOS and MAS (ClO) data by Michelsen et al. [1996] adds further support for an additional production channel for $\mathrm{HCl}$. Similar conclusions were reached by Chandra et al. [1993], who found that submillimeter heterodyne measurements of $\mathrm{ClO}$ and $\mathrm{HCl}$ [Stachnik et al., 1992] and the observed abundance and seasonal variation of $\mathrm{O}_{3}$ near 40 $\mathrm{km}$ were better simulated by allowing for the additional pathway for production of $\mathrm{HCl}$.

A more recent theoretical study [Crutzen et al., 1995] on the balance of production and loss of odd oxygen based on constraints provided by HALOE measurements of $\mathrm{HCl}$, $\mathrm{NO}_{2}, \mathrm{H}_{2} \mathrm{O}$, and $\mathrm{O}_{3}$ found that production usually exceeds loss in the middle and upper stratosphere, especially above $45 \mathrm{~km}$. The study of Dessler et al. [1996] took the analysis of UARS data one step further by incorporating MLS measurements of $\mathrm{ClO}$ and $\mathrm{O}_{3}$ and CLAES observations of $\mathrm{NO}_{2}$ at 40 and $46 \mathrm{~km}$, using the diurnal variation of the radicals, to discuss production and loss of $\mathrm{O}_{3}$. Their model overestimates the measured $\mathrm{ClO}$ by an amount consistent with that shown in our study and use of the measured $\mathrm{ClO}$ brought their modeled production and loss of ozone into near balance. The Dessler et al. study further states that by considering MLS measurements of $\mathrm{O}_{3}$ instead of HALOE values, the $\mathrm{O}_{3}$ surplus found by Crutzen et al. would instead be a deficit.

\section{Conclusions}

We have used the first set of simultaneous measurements of the radicals that dominate loss of ozone in the middle stratosphere to test our understanding of the partitioning of these radicals and to determine the relative contribution of each radical family to loss of ozone. The accuracy of this set of radical measurements is sufficient to demonstrate that (1) $\mathrm{NO}_{x}$ loss cycles dominate ozone loss between 24 and $38 \mathrm{~km}$, as predicted by models; (2) modeled $\mathrm{NO}_{x}$ and $\mathrm{HO}_{x}$ catalyzed loss rates of ozone are consistent with the measurements; (3) $\mathrm{Cl}_{x}$ loss rates are measured to be about a factor of 2 slower than the calculated rates above $30 \mathrm{~km}$; (4) the measured total loss rates of ozone balance production rates at 32 and $38 \mathrm{~km}$; and (5) inclusion of a channel for extra production of $\mathrm{HCl}$ in the photochemical model results in a balance between production and loss of $\mathrm{O}_{3}$ above $31 \mathrm{~km}$ and agreement between observed and calculated $\mathrm{ClO}, \mathrm{HOCl}$, and $\mathrm{HCl}$. These conclusions demonstrate that our first-order understanding of processes that regulate the partitioning of radicals is correct and that models, provided they allow for production of $\mathrm{HCl}$ either by the reaction of $\mathrm{ClO}$ and $\mathrm{OH}$ or by some other currently unknown process that results in a similar partitioning of inorganic chlorine species should provide a realistic description of the relative rate of removal of odd oxygen in the lower and middle stratosphere by each of the major catalytic cycles.

Acknowledgments We are grateful to the Jet Propulsion Laboratory Atmospheric Ballooning group for gondola support and to the National Scientific Balloon Facility for launch services. The work at SAO was supported by NASA grant NSG-5175. Research at the Jet Propulsion Laboratory, California Institute of Technology, was performed under contract with NASA.

\section{References}

Bates, D. R., and M. Nicolet, The photochemistry of atmospheric water vapor, J. Geophys. Res.55, 301, 1950.

Chance, K. V., W. A. Traub, D. G. Johnson, K. W. Jucks, P. Ciarpallini, R. A. Stachnik, R. A. Salawitch, and H. A. Michelsen, Simultaneous measurements of stratospheric $\mathrm{HO}_{x}, \mathrm{NO}_{x}$, and $\mathrm{Cl}_{x}$ : Comparison with a photochemical model, J. Geophys. Res.101, 9031, 1996.

Chandra, S., C. H. Jackman, A. R. Jackman, E. L. Fleming, and D. B. Considine, Chlorine catalyzed destruction of ozone: Implications for ozone variability in the upper stratosphere, Geophys. Res. Lett.20, 3511, 1993. 
Chapman, S., On ozone and atomic oxygen in the upper atmosphere, Philos. Mag., 10, 369, 1930.

Crutzen, P. J., The influence of nitrogen oxides on the atmospheric ozone content, Q. J. R. Meteorol. Soc., 96, 320, 1970.

Crutzen, P. J., and U. Schmailzl, Chemical budgets of the stratosphere, Planet. Space Sci., 31, 1009, 1983.

Crutzen, P. J., J.-U. Grooss, C. Bruhl, R. Muller, and J. M. Russell III, A reevaluation of the ozone budget with HALOE UARS data: No evidence for the ozone deficit, Science, 268, 705, 1995.

DeMore, W. B., S. P. Sander, D. M. Golden, R. F. Hampson, M. J. Kurylo, C. J. Howard, A. R. Ravishankara, C. E. Kolb, and M. J. Molina, Chemical kinetics and photochemical data for use in stratospheric modeling: Evaluation number 11, JPL Pub. 94-26, 1994.

Dessler, A. E., S. R. Kawa, D. B. Considine, J. W. Waters, L. Froidevaux, and J. B. Kumer, UARS measurements of $\mathrm{ClO}$ and $\mathrm{NO}_{2}$ at 40 and $46 \mathrm{~km}$ and implications for the model ozone deficit, Geophys. Res. Lett.23, 339, 1996.

Eckman, R. S., L. L. Grose, R. E. Turner, W. T. Blackshear, J. M. Russell, L. Froidevaux, J. W. Waters, J. B. Kumer, and A. E. Roche, Stratospheric trace constituents simulated by a three-dimensional general circulation model: Comparison with UARS data, J. Geophys. Res.100, 13,951, 1995.

Eluszkiewicz, J., and M. Allen, A global analysis of the ozone deficit in the upper stratosphere and lower mesosphere, J. Geophys. Res.98, 1069, 1993.

Elkins, J. W., T. M. Thompson, T. H. Swanson, J. H. Butler, B. D. Hall, S. O. Cummings, D. A. Fisher, and A. G. Raffo, Decrease in the growth rates of atmospheric chlorofluorocarbons 11 and 12, Nature, 364, $780,1993$.

Fahey, D. W., K. K. Kelly, S. R. Kawa, A. F. Tuck, M. Loewenstein, K. R. Chan, and L. E. Heidt, Observations of denitrification and dehydration in the winter polar stratospheres, Nature, 344, 321, 1990.

Fahey, D. W., et al., In situ measurements constraining the role of sulphate aerosols in mid-latitude ozone depletion, Nature, 363, 509, 1993.

Froidevaux, L., M. Allen, and Y. L. Yung, A critical analysis of $\mathrm{ClO}$ and $\mathrm{O}_{3}$ in the mid-latitude stratosphere, J. Geophys. Res.90, 12,999, 1985.

Gunson, M. R., C. B. Farmer, R. H. Norton, R. Zander, C. P. Rinsland, J. H. Shaw, and B.-C. Gao, Measurements of $\mathrm{CH}_{4}, \mathrm{~N}_{2} \mathrm{O}, \mathrm{CO}, \mathrm{H}_{2} \mathrm{O}$, and $\mathrm{O}_{3}$ in the mid- dle atmosphere by the Atmospheric Trace Molecule Spectroscopy experiment on Spacelab 3, J. Geophys. Res.95, 13,867, 1990.

Hanson, D. R., and E. R. Lovejoy, The reaction of $\mathrm{ClNO}_{3}$ with submicron sulfuric acid aerosol, Science, 267, $1326,1995$.

Hanson, D. R., and A. R. Ravishankara, Reactive uptake of $\mathrm{ClNO}_{3}$ onto sulfuric acid due to reaction with $\mathrm{HCl}$ and $\mathrm{H}_{2} \mathrm{O}$, J. Phys. Chem., 98, 5728, 1994.

Hanson, D. R., and A. R. Ravishankara, Heterogeneous chemistry of bromine species in sulfuric acid under stratospheric conditions, Geophys. Res. Lett.22, 385, 1995.

Jackman, C. H., R. S. Stolarski, and J. A. Kaye, Twodimensional monthly average ozone balance from limb infrared monitor of the stratosphere and stratospheric and mesospheric sounder data, J. Geophys. Res.91, $1103,1986$.

Johnson, D. G., K. W. Jucks, W. A. Traub, and K. V. Chance, Smithsonian stratospheric far-infrared spectrometer and data reduction system, J. Geophys. Res.100, 3091, 1995.

Johnston, H., Reduction of stratospheric ozone by nitrogen oxide catalysts from supersonic transport exhaust, Science, 173, 517, 1971.

Ko, M. K. W., N. D. Sze, and D. K. Weisenstein, The roles of dynamical and chemical processes in determining the stratospheric concentration of ozone in one-dimensional and two-dimensional models, J. Geophys. Res.94, 9889, 1989.

McElroy, M. B., and R. J. Salawitch, Changing composition of the global stratosphere, Science, 243, 763, 1989.

McElroy, M. B., R. J. Salawitch, S. C. Wofsy, and J. A. Logan, Reductions of antarctic ozone due to synergistic interactions of chlorine and bromine, Nature, 321, 759, 1986.

McElroy, M. B., R. J. Salawitch, and K. Minschwaner, The changing stratosphere, Planet. Space Sci., 40, 373, 1992.

Michelsen, H. A., et al, Stratospheric chlorine partitioning: Constraints from shuttle-borne measurements of $[\mathrm{HCl}],\left[\mathrm{ClNO}_{3}\right]$, and [ClO], Geophys. Res. Lett.23, 2361, 1996.

Minschwaner, K., R. J. Salawitch, and M. B. McElroy, Absorption of solar radiation by $\mathrm{O}_{2}$ : Implications for $\mathrm{O}_{3}$ and lifetimes of $\mathrm{N}_{2} \mathrm{O}, \mathrm{CFCl}_{3}$, and $\mathrm{CF}_{2} \mathrm{Cl}_{2}$, J. Geophys. Res.98, 10,543, 1993. 
Molina, M. J., and F. S. Rowland, Stratospheric sink for chlorofluoromethanes: Chlorine atom catalyzed destruction of ozone, Nature, 249, 810, 1974.

Perliski, L. M., S. Solomon, and J. London, On the interpretation of seasonal variations of stratospheric ozone, Planet. Space Sci., 37, 1527, 1989.

Prather, M. J., Ozone in the upper stratosphere and mesosphere, J. Geophys. Res.86, 5325, 1981.

Prather, M. J., and E. E. Remsberg (Eds.), The atmospheric effects of stratospheric aircraft: Report of the 1992 models and measurement workshop, NASA Ref. Publ. 1292, vol. I, 63, 1993.

Rodriguez, J. M., M. K. W. Ko, N. D. Sze, C. W. Heisey, G. K. Yue, and M. P. McCormick, Ozone response to enhanced heterogeneous processing after the eruption of Mt. Pinatubo, Geophys. Res. Lett.21, 209, 1994.

Salawitch, R. J., et al., The distribution of hydrogen, nitrogen, and chlorine radicals in the lower stratosphere: Implications for changes in $\mathrm{O}_{3}$ due to emission of $\mathrm{NO}_{y}$ from supersonic aircraft, Geophys. Res. Lett.21, 2547, 1994.

Schauffler, S. M., L. E. Heidt, W. H. Pollock, T. M. Gilpin, J. F. Vedder, S. Solomon, R. A. Lueb, and E. L. Atlas, Measurements of halogenated organic compounds near the tropical tropopause, Geophys. Res. Lett.20, 2567, 1993.

Siskind, D. E., B. J. Connor, R. S. Eckman, E. E. Remsberg, J. J. Tsou, and A. Parrish, An intercomparison of model ozone deficits in the upper stratosphere and mesosphere from two data sets, J. Geophys. Res.100, 11,191, 1995.

Stachnik, R. A., J. C. Hardy, J. A. Tarsala, and J. W. Waters, Submillimeterwave heterodyne measurements of stratospheric $\mathrm{ClO}, \mathrm{HCl}, \mathrm{O}_{3}$, and $\mathrm{HO}_{2}$ : First results, Geophys. Res. Lett.19, 1931, 1992.

Stolarski, R. S., and R. J. Cicerone, Stratospheric chlorine: a possible sink for ozone, Can. J. Chem., 52, 1610, 1974.

Stolarski, R. S. and H. L. Wesoky (Eds.), The atmospheric effects of stratospheric aircraft: A second program report, NASA Ref. Publ. 1313, 1, 1993.

Traub, W. A., K. V. Chance, D. G. Johnson, and K. W. Jucks, Stratospheric spectroscopy with the far-infrared spectrometer (FIRS 2): Overview and recent results, SPIE, 1491, 298, 1991.

Waters, J. W., J. C. Hardy, R. F. Jarnot, H. M. Pickett, and P. Zimmermann, A balloon-borne microwave limb sounder for stratospheric measurements, J. Quant. Spectrosc. Radiat. Transfer, 32, 407, 1984.

Wennberg, P. O., et al., Removal of stratospheric $\mathrm{O}_{3}$ by radicals: In situ measurements of $\mathrm{OH}, \mathrm{HO}_{2}, \mathrm{NO}, \mathrm{NO}_{2}$, $\mathrm{ClO}$, and BrO, Science, 266, 398, 1994.

World Meteorological Organization (WMO), Atmospheric ozone 1985: Assessment of our understanding of the processes controlling its present distribution and change, WMO-Rep. 16, Global Ozone Res. and Monit. Proj., Geneva, Switzerland, 1986.

World Meteorological Organization (WMO), Scientific assessment of ozone depletion: 1991, WMO-Rep. 25, Global Ozone Res. and Monit. Proj., Geneva, Switzerland, 1991.

Wofsy, S. C., M. B. McElroy, and Y. L. Yung, The chemistry of atmospheric bromine, Geophys. Res. Lett.2, $215,1975$.

Woodbridge, J. W., et al., Estimates of total organic and inorganic chlorine in the lower stratosphere from in situ measurements during AASE II, J. Geophys. Res.100, 3057, 1995.
This preprint was prepared with the AGU LATEX macros v3.1. File o3loss formatted 1999 March 11. 